\title{
Determinan Kejadian Overweight pada Wanita Usia Subur di Kota Jambi
}

\author{
M. Dody Izhar \\ Fakultas Kesehatan Masyarakat, Universitas Jambi ${ }^{1}$ \\ *Correspondence email: mdodyizhar@unja.ac.id
}

\begin{abstract}
Abstrak. Overweight merupakan salah satu permasalahan gizi di Indonesia yang akan mempengaruhi kualitas kesehatan. Peningkatan prevalensi kegemukan di identifikasi lebih berisiko pada kelompok wanita seiring dengan pertambahan usia. Adapun determinan lain diantaranya penggunaan alat kontrasepsi, asupan makanan yang tidak sesuai dengan kebutuhan, kurangnya aktivitas serta adanya riwayat keluarga. Penelitian ini bertujuan untuk mengetahui dan mengidentifikasi upaya pencegahan terhadap faktor risiko yang memungkinkan menjadi faktor penentu terhadap kegemukan pada wanita usia subur. Penelitian ini merupakan penelitian observasional dengan menggunakan rancangan cross sectional. Pengambilan sampel menggunakan teknik multistage random sampling dengan besar sampel sebanyak 276 responden di Wilayah Kerja Puskesmas Simpang Kawat Kota Jambi Tahun 2019, penelitian telah dilaksanakan pada bulan Agustus 2018-Juli 2019. Data di analisis menggunakan uji chi square $(\alpha=0,05)$. Hasil penelitian menunjukkan bahwa prevalensi kegemukan pada wanita usia subur sebesar $35,5 \%$, pola makan buruk $(50,4 \%)$, aktivitas fisik berat $(81,9 \%)$, tidak ada riwayat kegemukan pada keluarga $(80,4 \%)$ dan penggunaan kontrasepsi hormonal $(60,9 \%)$. Berdasarkan analisis komparatif diketahui bahwa faktor yang signifikan dengan kejadian overweight yaitu variabel pola makan $(p$ value $=0,019)$, sedangkan faktor lain dinyatakan tidak signifikan yaitu aktivitas fisik; baik aktivitas ringan $(p$ value $=$ $0,596)$ dan sedang $(p$ value $=0,216)$, riwayat keluarga $(p$ value $=0,126)$ dan penggunaan alat kontrasepsi; baik hormonal $(p$ value $=$ $0,485)$ dan non hormonal $(p$ value $=0,505)$. Kesimpulan dari penelitian ini adalah determinan kejadian overweight pada wanita usia subur disebabkan oleh pola makan yang buruk dan tidak dipengaruhi oleh aktivitas fisik, riwayat keluarga dan penggunaan alat kontrasepsi.
\end{abstract}

Kata Kunci: Aktivitas; Kontrasepsi; Makanan; Overweight; Riwayat.

Abstract. Overweight is one of the nutritional problems in Indonesia that will affect the quality of health. Increased prevalence of obesity is identified as being more at risk in the group of women as they age. As for other determinants including the use of contraception, food intake that is not in accordance with needs, lack of activity and family history. This study aims to determine and identify preventive measures against risk factors that may be a determining factor for overweight in women of childbearing age. This study was an observational study using a cross sectional design. Sampling using a multistage random sampling technique with a sample size of 276 respondents in the Simpang Kawat Puskesmas Work Area in Jambi City in 2019, the study was conducted in August 2018-July 2019. Data were analyzed using the chi square test $(\alpha=0.05)$. The results showed that the prevalence of obesity in women of childbearing age was 35.5\%, poor diet (50.4\%), heavy physical activity (81.9\%), no family history of obesity (80.4\%) and use hormonal contraception (60.9\%). Based on comparative analysis, it is known that a significant factor with overweight is eating variable $(p$ value $=0.019)$, while other factors are declared insignificant namely physical activity; both mild activity ( $p$ value $=0.596)$ and moderate $(p$ value $=0.216)$, family history $(p$ value $=0.126)$ and use of contraception; both hormonal ( $p$ value $=0.485$ ) and non hormonal $(p$ value $=0.505)$. The conclusion of this study is the determinant of the incidence of overweight in women of childbearing age caused by poor diet and is not influenced by physical activity, family history and use of contraception.

Keywords: Activity; Contraception; Dietary; Overweight; History.

\section{PENDAHULUAN}

Pencapaian indeks pembangunan manusia tidak terlepas dari segi peningkatan kualitas kesehatan. Namun, saat ini banyak masalah gizi yang dapat mempengaruhi kualitas kesehatan salah satunya adalah masalah overweight (kegemukan). Pencegahan epidemi overweight merupakan salah satu tantangan besar gizi dan kesehatan masyarakat baik di negara maju maupun negara berkembang. Prevalensi overweight cenderung meningkat seiring dengan peningkatan usia dan puncaknya pada usia dewasa (Diana, 2013).

Berdasarkan Data World Health Organization (WHO) Tahun 2018 menunjukkan lebih dari 1,9 miliar orang dewasa berusia 18 tahun dan lebih tua mengalami kelebihan berat badan. Dari jumlah ini, lebih dari 650 juta orang dewasa mengalami obesitas. Pada Tahun 2016 sebanyak $39 \%$ orang dewasa berusia 18 tahun ke atas (39\% pria dan $40 \%$ wanita) mengalami kelebihan berat badan. Secara keseluruhan, sekitar $13 \%$ populasi dewasa dunia (11\% pria dan $15 \%$ wanita) mengalami obesitas pada Tahun 2016. Prevalensi obesitas di seluruh dunia meningkat hampir tiga kali lipat antara Tahun 1975 sampai 2016.

Berdasarkan Riset Kesehatan Dasar (Riskesdas) Tahun 2018 oleh Kementerian Kesehatan RI, menunjukkan bahwa prevalensi overweight dan obesitas di Indonesia untuk usia dewasa ( $>18$ tahun) berdasarkan pengukuran Indeks Masa Tubuh (IMT) $\geq 25,0 \mathrm{~s} / \mathrm{d}<27,0$ termasuk dalam kategori overweight dan IMT $\geq 27$ termasuk dalam kategori obesitas cenderung mengalami 
peningkatan, yaitu tahun 2007 kejadian overweight sebesar $8,6 \%$, dan obesitas sebesar $10,5 \%$, pada Tahun 2013 kejadian overweight sebesar $11,5 \%$ dan obesitas sebesar 14,8\% serta meningkat pada Tahun 2018 kejadian overweight sebesar 13,6\% dan obesitas sebesar $21,8 \%$. Perempuan overweight dan obesitas memiliki prevalensi lebih tinggi sebesar $14,8 \%$ dan $24 \%$ dibandingkan laki-laki overweight dan obesitas sebesar $11,9 \%$ dan $11,5 \%$. Provinsi Jambi menempati posisi tujuh belas dari 33 provinsi dengan prevalensi sebesar $13,3 \%$.

Berdasarkan data yang diperoleh dari Dinas Kesehatan Kota Jambi bahwa data yang tersedia hanya data obesitas. Data tersebut sebagai gambaran permasalahan overweight yang ada di Kota Jambi pada saat ini. Berdasarkan data dapat dilihat dari Tahun 2016 sampai 2018 mengalami peningkatan prevalensi kasus obesitas. Pada Tahun 2016 obesitas merupakan kasus baru terbanyak pada PTM yaitu obesitas merupakan urutan ke-5 dengan prevalensi sebesar 5\%. Pada Tahun 2017 obesitas merupakan urutan ke-3 dengan prevalensi sebesar 7,1\%. Sedangkan pada Tahun 2018 obesitas tetap bertahan pada urutan ke-3 dengan prevalensi yang meningkat sebesar $10 \%$. (Dinas Kesehatan Kota Jambi, 2016, 2017, 2018).

Puskesmas Simpang Kawat memiliki jumlah kasus obesitas terbanyak dibandingkan Puskesmas lain dengan jumlah kasus sebanyak 647 kasus di Tahun 2018. Selain itu, Puskesmas Simpang Kawat memiliki prevalensi obesitas tertinggi pada Tahun 2018 sebesar $7,5 \%$. Wilayah Kerja Puskesmas Simpang Kawat mencakup 4 kelurahan, salah satunya Kelurahan Payo Lebar memiliki jumlah kasus obesitas terbanyak dibandingkan kelurahan lain dengan jumlah kasus sebanyak 181 kasus pada Tahun 2018.

Banyak faktor penyebab terjadinya kegemukan seperti faktor genetik, faktor lingkungan dan perilaku makan yang kurang tepat. Faktor lingkungan dan perilaku dikatakan faktor yang memberikan kontribusi yang lebih besar terhadap kegemukan. Faktor perilaku dan lingkungan sangat erat kaitannya dengan gaya hidup masyarakat. Gaya hidup masyarakat saat ini sudah mengarah pada gaya hidup modern yang ditandai dengan pola makan yang kebaratan dengan ciri-ciri makanan yang tinggi karbohidrat, tinggi lemak dan rendahnya asupan serat yang disertai dengan kurangnya aktivitas fisik yang dilakukan oleh masyarakat (Hardiansyah, 2016).

Selain itu faktor lain yang dapat mempengaruhi kejadian kegemukan adalah penggunaan alat kontrasepsi hormonal (suntik, pil, implant) juga dapat meningkatkan berat badan disebabkan oleh hormon dalam kontrasepsi yaitu esterogen dan progesteron. Esterogen menyebabkan pengeluaran natriun dan air berkurang sehingga terjadi penimbunan cairan, sedangkan progesteron akan mempermudah perubahan karbohidrat dan gula menjadi lemak, merangsang nafsu makan serta menurunkan aktivitas fisik sehingga terjadi peningkatan berat badan (Wiknjosastro, 2005).

Berdasarkan uraian diatas maka dari itu peneliti tertarik untuk melakukan penelitian di Wilayah Kerja Puskesmas Simpang Kawat dengan judul "Determinan Kejadian Overweight pada Wanita Usia Subur di Wilayah Kerja Puskesmas Simpang Kawat Kota Jambi Tahun 2019".

\section{METODE}

Jenis penelitian yang digunakan adalah studi observasional analitik dengan rancangan Cross Sectional. Tempat penelitian ini dilakukan di Kelurahan Payo Lebar di wilayah kerja Puskesmas Simpang Kawat Kota Jambi. Waktu penelitian ini telah dilaksanakan dari bulan September 2018-Juli 2019. Populasi dalam penelitian ini adalah seluruh wanita yang berusia 18 tahun ke atas yang bertempat tinggal di Kelurahan Payo Lebar berjumlah 4.564 orang. Sampel pada penelitian ini sebanyak 276 responden. Kriteria Inklusi pada penelitian ini adalah wanita yang berusia $\geq 18-49$ tahun, belum mengalami menopause, wanita usia subur yang telah menikah, bersedia menjadi responden dengan menandatangani informed consent, masyarakat yang berdomisili di Kelurahan Payo Lebar sekurangkurangnya 1 tahun, variabel terikat dalam peneitian ini adalah kegemukan, sedangkan variabel bebas adalah aktivitas fisik, pola makan, riwayat keluarga dan penggunaan alat kontrasepsi.

Instrumen pengukuran status gizi (overweight) dengan indikator IMT (timbangan injak digital dan microtoise), pola makan menggunakan Food Frequency Questionnaire (FFQ) berdasarkan Survey Konsumsi Pangan 2018 (Sirajudin, 2018) aktivitas fisik menggunakan Global Physical Activity (GPAQ), (WHO 2019a, 2019b). Sedangkan informasi pemakaian alat kontrasepsi dan riwayat overweight keluarga menggunakan kuesioner tertutup.

Pengolahan data dilakukan secara deskriptif dari distribusi karakteristik responden (usia, Pendidikan dan pekerjaan), distribusi frekuensi variabel penelitian dan analisis komparatif menggunakan metode uji chi square untuk mengetahui tingkat signifikansi variabel pola makan, aktivitas fisik, riwayat keluarga dan penggunaan metode kontrasepsi dengan kejadian overweight pada wanita usia subur di wilayah kerja Puskesmas Simpang Kawat Kota Jambi Tahun 2019.

\section{HASIL DAN PEMBAHASAN Karakteristik responden}

Gambaran umum karakteristik responden di wilayah kerja Puskesmas Simpang Kawat Kota Jambi meliputi usia, pendidikan dan pekerjaan tersaji pada Tabel 1: 
Tabel 1. Distribusi Karakteristik Responden

\begin{tabular}{lcc}
\hline \multicolumn{1}{c}{ Variabel } & $\begin{array}{c}\text { Jumlah } \\
(\mathbf{n : ~ 2 7 6 )}\end{array}$ & $\begin{array}{c}\text { Persentase } \\
(\boldsymbol{\%})\end{array}$ \\
\hline Usia & 26 & \\
$18-25$ & 52 & 9,4 \\
$26-33$ & 105 & 18,8 \\
$34-41$ & 93 & 38,1 \\
$42-49$ & & 33,7 \\
\hline Pendidikan & 37 & \\
Tamat SD/MI & 58 & 13,4 \\
Tamat SMP/MTS & 107 & 21,0 \\
Tamat SMA/MA & 74 & 38,8 \\
Tamat Sarjana & & 26,8 \\
\hline Pekerjaan & 19 & \\
PNS/TNI/POLRI/BUMN & 19 & 6,9 \\
Pegawai swasta & 65 & 6,9 \\
Wiraswasta & 173 & 23,5 \\
Ibu Rumah Tangga & & 62,7 \\
\hline
\end{tabular}

Pada Tabel 1 menunjukkan bahwa usia responden terbanyak berusia $34-41$ tahun $(38,1 \%)$, pendidikan responden terbanyak pada tingkat tamat SMA/MA $(38,8 \%)$ yang mayoritas perkerjaannya adalah sebagai ibu rumah tangga $(62,7 \%)$.

\section{Distribusi variabel penelitian}

Data distribusi frekuensi responden berdasarkan indeks massa tubuh (IMT), pola makan, aktivitas fisik, riwayat keluarga dan penggunaan alat kontrasepsi yang selanjutnya data tersebut dikelompokan.

Diketahui bahwa dari 276 responden: 98 responden $(35,5 \%)$ mengalami overweight. Sedangkan distribusi frekuensi berdasarkan determinan pola makan dengan kategori buruk sebanyak 139 responden $(50,4 \%)$, aktifitas fisik berat sebanyak 226 responden $(81,9 \%)$, tidak memiliki riwayat keluarga overweight sebanyak 222 responden $(80,4 \%)$ dan penggunaan kontrasepsi hormonal sebanyak 168 responden $(60,9 \%)$. Adapun data tersebut dapat disajikan pada Tabel 2 berikut ini:

Tabel 2. Distribusi frekuensi responden berdasarkan pola makan, aktivitas fisik, riwayat keluarga, penggunaan alat kontrasepsi

\begin{tabular}{rcc}
\hline Variabel & $\begin{array}{c}\text { Jumlah } \\
(\mathbf{n : ~ 2 7 6})\end{array}$ & $\begin{array}{c}\text { Persentase } \\
(\%)\end{array}$ \\
\hline $\begin{array}{c}\text { Indeks Massa Tubuh } \\
\text { Overweight }\end{array}$ & 98 & 35,5
\end{tabular}

\begin{tabular}{lcc} 
Normal & 178 & 64,5 \\
\hline Pola Makan & & \\
$\quad$ Buruk & 139 & 50,4 \\
Baik & 137 & 49,6 \\
\hline Aktivitas Fisik & & \\
$\quad$ Ringan & 4 & 1,4 \\
Sedang & 46 & 16,7 \\
$\quad$ Berat & 226 & 81,9 \\
\hline Riwayat Keluarga & & \\
$\quad$ Ada & 54 & 19,6 \\
$\quad$ Tidak ada & 222 & 80,4 \\
\hline Penggunaan Alat Kontrasepsi & & \\
$\quad$ Hormonal & 168 & 60,9 \\
$\quad$ Non hormonal & 15 & 5,4 \\
$\quad$ Tidak Menggunakan & 93 & 33,7 \\
\hline
\end{tabular}

\section{Hasil analisis}

Berdasarkan hasil analisis (Tabel 3), pola makan, aktivitas fisik, riwayat keluarga dan penggunaan alat kontrasepsi terhadap kejadian overweight diketahui bahwa pola makan memiliki nilai $p$ value $=0,019(p$ value < 0,05$)$ yang berarti bahwa pola makan secara signifikan berhubungan dengan indeks massa tubuh pada wanita usia subur. Berdasarkan hasil perhitungan nilai $\mathrm{PR}=1,230 \quad(95 \% \mathrm{CI}=1,034-1,476)$, sehingga dapat disimpulkan bahwa wanita usia subur dengan pola makan yang buruk memiliki risiko 1,230 kali untuk menderita overweight jika dibandingkan dengan wanita memiliki pola makan baik.

Hasil analisis antara aktivitas fisik ringan dengan pembanding aktivitas fisik berat menunjukkan bahwa nilai $p$ value $=0,596$ ( $p$ value $>0,05)$ dengan nilai $\mathrm{PR}=$ $1,569(95 \% \mathrm{CI}=0,578-4,259)$; dan aktivitas fisik sedang dan pembanding aktivitas berat menunjukkan bahwa nilai $p$ value $=0,216$ ( $p$ value $>0,05)$ dengan nilai $\mathrm{PR}=$ $1,630(95 \% \mathrm{CI}=0,702-2,292)$ terhadap indeks massa tubuh tidak berhubungan secara singnifikan dengan kejadian overweight pada wanita usia subur.

Hasil analisis determinan riwayat keluarga dengan indeks massa tubuh menunjukkan bahwa nilai $p$ value $=$ $0,126(p$ value $>0,05)$ dengan nilai $\mathrm{PR}=1,330(95 \% \mathrm{CI}=$ 0,938-1,895), sehingga dapat disimpulkan bahwa adanya riwayat keluarga yang overweight tidak berhubungan secara signifikan dengan kejadian overweight pada wanita subur.

Tabel 3. Hasil analisis determinan overweight pada wanita usia subur di Wilayah Kerja Puskesmas Simpang Kawat Jambi (N: 276)

\begin{tabular}{|c|c|c|c|c|c|c|c|c|}
\hline \multirow{3}{*}{ Variabel } & \multicolumn{4}{|c|}{ Indeks Massa Tubuh (IMT) } & \multirow{2}{*}{\multicolumn{2}{|c|}{ Total }} & \multirow{3}{*}{ P-Value } & \multirow{3}{*}{$\begin{array}{c}\text { PR } \\
(95 \% \mathrm{CI})\end{array}$} \\
\hline & \multicolumn{2}{|c|}{ Overweight } & \multicolumn{2}{|c|}{ Normal } & & & & \\
\hline & $\mathbf{n}$ & $\%$ & $\bar{n}$ & $\%$ & $\mathbf{N}$ & $\%$ & & \\
\hline \multicolumn{9}{|l|}{ Pola makan } \\
\hline Buruk & 40 & 28,8 & 99 & 71,2 & 139 & 100 & \multirow{2}{*}{$0,019 *$} & \multirow{2}{*}{$1,230(1,034-1,476)$} \\
\hline Baik & 58 & 42,3 & 79 & 57,7 & 137 & 100 & & \\
\hline \multicolumn{9}{|l|}{ Aktivitas fisik } \\
\hline Ringan & 2 & 50,0 & 2 & 50,0 & 4 & 100 & 0,596 & $1,569(0,578-4,259)$ \\
\hline Sedang & 24 & 52,2 & 22 & 47,8 & 46 & 100 & 0,216 & $1,630(0,702-2,292)$ \\
\hline Berat & 72 & 31,9 & 154 & 68,1 & 226 & 100 & Reference & \\
\hline \multicolumn{9}{|l|}{ Riwayat keluarga } \\
\hline Ada & 24 & 44,4 & 30 & 55,6 & 54 & 100 & 0,126 & $1,330(0,938-1,895)$ \\
\hline
\end{tabular}




\begin{tabular}{lcccccccc}
\hline Tidak ada & 74 & 33,3 & 148 & 66,7 & 222 & 100 & & \\
Penggunaan alat kontrasepsi & & & & & & & & \\
$\quad$ Hormonal & 56 & 33,3 & 112 & 66,7 & 168 & 100 & 0,485 & $1,069(0,883-1,294)$ \\
$\quad$ Non hormonal & 7 & 46,7 & 8 & 53,3 & 15 & 100 & 0,505 & $1,240(0,680-2,262)$ \\
$\quad$ Tidak pengguna & 35 & 37,6 & 58 & 62,4 & 93 & 100 & Reference & \\
\hline$* p<0,05$ & & & & & & &
\end{tabular}

Sedangkan determinan penggunaan alat kontrasepsi hormonal dan non hormonal dengan pembanding tidak menggunakan metode kontrasepsi apapun terhadap indeks massa tubuh menunjukkan hasil yang tidak signifikan ( $p$ value $>0,05)$ dengan masingmasing hasil analisis: $p$ value $=0,485, P R=1,069$ $(95 \% \mathrm{CI}=0,883-1,294) ;$ dan $\mathrm{p}$ value $=0,505, \mathrm{PR}=1,240$ $(95 \% \mathrm{CI}=0,680-2,262)$. Dengan demikian dapat disimpulkan penggunaan alat kontrasepsi hormonal dan non hormonal bukan merupakan determinan yang berhubungan dengan kejadian overweight maupun obesitas pada wanita usia subur.

\section{Pembahasan}

\section{Hubungan Pola Makan dengan Overweight}

Berdasarkan hasil penelitian bahwa pola makan memiliki hubungan yang signifikan dengan kejadian overweight pada wanita. Hasil penelitian ini sesuai dengan teori yang menyatakan bahwa terdapat hubungan antara pola makan dengan kejadian overweigth pada wanita. Pola makan yang baik yaitu sesuai dengan kebutuhan disertai pemilihan bahan makanan yang tepat akan berdampak pada status gizi baik. Dimana asupan makanan yang melebihi kebutuhan tubuh akan menyebabkan kelebihan berat badan dan atau penyakit lain yang disebabkan oleh kelebihan gizi. Sebaliknya, asupan makanan kurang dari yang dibutuhkan akan menyebabkan tubuh menjadi kurus dan rentan terhadap penyakit (Sulistyoningsih, 2011).

Perilaku dalam mengkonsumsi makanan dalam jumlah banyak dan tidak seimbang dapat menyebabkan keadaan gizi lebih selanjutnya membawa risiko terhadap masalah kesehatan terutama penyakit degenerative. Berdasarkan hasil temuan peneliti dilapangan bahwa sebagian besar responden mempunyai kebiasaan mengkonsumsi karbohidrat dalam jumlah yang banyak seperti mengkonsumsi nasi yang lebih dari tiga kali per hari, mengkonsumsi mie basah, mie kering, kentang, dan roti.

Hal ini juga sesuai dengan teori dari Almatsier (2009) dimana seseorang yang memakan karbohidrat dalam jumlah berlebihan dapat menyebabkan tubuh menjadi gemuk. Hal ini sejalan dengan penelitian yang dilakukan oleh Putra (2017) di SMA Negeri 5 Surabaya yang menunjukkan ada hubungan antara pola makan dengan kejadian overweight pada siswa SMA Negeri 5 Surabaya. Selain itu, responden dengan pola makan berlebih mempunyai kecenderungan 2,6 kali lebih besar terjadinya overweight dari pada responden dengan pola makan cukup dan kurang.
Hasil penelitian ini sejalan dengan penelitian yang dilakukan Yulianawati (2016) mengenai hubungan pola makan dengan tingkat obesitas pada Mahasiswa Ilmu Keperawatan di Universitas Aisyiyah Yogyakarta menunjukkan hasil $p$ value $=0,030$ yang berarti pola makan memiliki hubungan yang bermakna dengan kejadian overweight. Frekuensi makan adalah jumlah makan dalam sehari, hasil penelitian diperoleh prevalensi frekuensi makan lebih dari 3 kali sehari lebih besar dibanding dengan prevalensi makan 2 kali sehari.

Penelitian tersebut juga sejalan dengan penelitian yang dilakukan oleh Evan dkk (2017) menunjukkan adanya hubungan antara pola makan dengan kejadian overweight pada mahasiswa di Universitas Tribhuhawana Tunggadewi Malang. Pola makan yang berlebih dapat menjadi faktor terjadinya overweight. Overweight terjadi jika seseorang mengkonsumsi kalori melebihi jumlah kalori yang dibakar. Pada hakikatnya, tubuh memerlukan asupan kalori untuk kelangsungan hidup dan aktivitas fisik, namun untuk menjaga berat badan perlu adanya keseimbangan antara energi yang masuk dengan energi yang keluar. Keseimbangan energi yang terjadi dapat mengarah pada kelebihan berat badan dan obesitas.

Makanan merupakan sumber dari asupan energi. Di dalam makanan yang akan diubah menjadi energi adalah zat gizi penghasil energi yaitu karbohidrat, protein, dan lemak. Apabila asupan karbohidrat, protein, dan lemak berlebih, maka karbohidrat akan disimpan sebagai glikogen dalam jumlah terbatas dan sisanya lemak. Protein akan dibentuk sebagai protein tubuh dan sisanya lemak, sedangkan lemak akan disimpan sebagai lemak. Tubuh memiliki kemampuan menyimpan lemak yang tidak terpakai untuk kebutuhan energi, bila tidak digunakan maka mengakibatkan overweight atau obesitas.

Hasil analisis yang berbeda dilakukan oleh Miko dkk (2017) menunjukkan tidak terdapat hubungan yang signifikan antara pola makan dengan kejadian obesitas pada mahasiswa jurusan Gizi di Politeknik. Hal ini juga sejalan dengan hasil penelitian yang dilakukan Rizka dkk (2014), menjelaskan tidak terdapat hubungan signifikan antara pola makan dengan obesitas. Perbedaan ini dapat terjadi karena sangat banyaknya faktor risiko terjadinya overweight dan obesitas. Hal-hal tersebut juga dipengaruhi oleh sosial dan budaya suatu daerah yang berpengaruh dengan gaya hidup masyarakat.

Berdasarkan hasil penelitian ini dapat disimpulkan bahwa terdapat hubungan antara pola makan dengan kejadian overweight. Rata-rata responden memiliki pola 
makan yang buruk. Dengan demikian pola makan yang tidak baik akan berdampak peningkatan indeks massa tubuh (overweight), dimana asupan makanan tidak sesuai dengan kebutuhan pada wanita usia subur dan berisiko pada kejadian gangguan atau penyakit lain yang disebabkan oleh kelebihan gizi. Sebaliknya asupan yang kurang dari kebutuhan tubuh dapat menyebabkan tubuh menjadi kurus dan rentan terhadap penyakit. Sehingga pengaturan pola makan (asupan zat gizi) yang baik adalah sesuai dengan kebutuhan tubuh berdasarkan kelompok usia, jenis kelamin dan aktivitas sehariharinya.

\section{Hubungan Aktivitas Fisik dengan Overweight}

Berdasarkan hasil penelitian diperoleh bahwa aktivitas fisik tidak memiliki hubungan yang singnifikan dengan kejadian overweight pada wanita subur. Kebiasaan aktivitas fisik yang dilakukan wanita dalam penelitian ini melakukan kegiatan dirumah walaupun dikategorikan sebagai aktivitas sedang bahkan berat dengan waktu kegiatan terus menerus dan lebih dari 10 menit dan sedikit waktu istirahat, dari hasil perhitungan diketahui bahwa rata-rata aktivitas 2250 METmenit/minggu. Hal tersebut dipertegas dengan hasil analisis komparatif data bahwa sebesar $68,1 \%$ dikategorikan aktivitas berat tidak mengalami overweight.

Menurut Hardiansyah dkk (2016), faktor risiko kedua tingginya overweight di masyarakat adalah aktivitas fisik kurang gerak. Kemajuan dibidang teknologi dan informasi memanjakan individu dan masyarakat dengan berbagai fasilitas yang mengurangi aktivitas fisiknya dalam melaksanakan kegiatan sehariharinya. Mereka tinggal duduk bekerja dengan di sekelilingnya dilengkapi dengan berbagai fasilitas komunikasi dan media.

Adanya berbagai fasilitas rumah tangga yang serba otomatis mengurangi gerak ibu rumah tangga, mereka dapat mengerjakan tugasnya sambil bermalasmalasam menonton televisi ditemani dengan makanan ringan yang cukup banyak sehingga tanpa disadari terjadi asupan yang berlebih disertai dengan aktivitas yang kurang. Namun dalam penelitian ini diketahui bahwa pada umumnya responden memiliki aktivitas yang dikelompokan berat, dengan akitivitas fisik yang berat ini membutuhkan energi yang banyak (menguras energi) sehingga mengakibatkan determinan aktivitas fisik tidak mempengaruhi kejadian kelebihan berat badan. Penelitian ini sejalan dengan penelitian yang dilakukan oleh Miko (2017) menunjukkan tidak ada hubungan yang signifikan antara berat badan dengan aktivitas fisik mahasiswa. Hal ini juga sejalan dengan hasil penelitian yang dilakukan oleh Merawati (2005) menunjukkan nilai $p$ value $=0,710$ yang artinya tidak ada hubungan yang signifikan antara aktivitas fisik dengan kejadian overweight. Dinyatakan bahwa pengeluaran energi yang banyak mempengaruhi pengurangan penimbunan lemak di dalam tubuh.

Namun berbeda dengan penelitian Nova (2017) hasil penelitian menunjukkan bahwa ada hubungan yang signifikan antara aktivitas fisik dengan kejadian overweight. Penelitian tersebut juga sejalan dengan penelitian yang dilakukan oleh Diana dkk (2013) menunjukkan terdapat hubungan yang signifikan antara aktivitas fisik dengan kejadian overweight dengan nilai $p$ value $=0,000$ dengan nilai $\mathrm{OR}=1,213$ yang berarti bahwa responden yang memiliki aktivitas fisik ringan berisiko 1,213 kali lebih besar untuk menjadi overweight. Subjek pada analisis ini merupakan perempuan yang sudah menikah dan rata-rata perkejaannya menjadi ibu rumah tangga. Pada analisis ini, aktivitas fisik berdasarkan jenis pekerjaan. Jenis pekerjaan yang tergolong aktivitas fisik ringan tersebut merupakan jenis pekerjaan yang tidak membutuhkan banyak usaha fisik, tidak perlu untuk berjalan kaki jarak jauh, umumnya menggunakan kendaraan bermotor untuk transportasi, dan menghabiskan sebagian besar waktunya dengan duduk atau sedikit gerakan badan.

Berdasarkan hasil penelitian ini dapat disimpulkan bahwa tidak terdapat hubungan antara aktivitas fisik dengan kejadian overweight. Rata-rata responden memiliki aktivitas fisik berat. Hal ini dikarenakan sebagian besar responden pekerjaannya adalah ibu rumah tangga yang mempunyai aktivitas yang cukup aktif serta sebagian besar responden rutin melakukan olahraga.

Pada aktivitas fisik berat adalah kegiatan yang secara terus menerus melakukan kegiatan aktivitas fisik minimal 10 menit sampai dengan meningkatnya denyut nadi dan bernafas lebih cepat dari biasanya (misalnya memasak, mencuci, menyapu, mengepel, mencuci dan mengurus anak dan lain-lain). Aktivitas fisik berat dilakukan minimal selama tiga hari dalam satu minggu dan total waktu untuk beraktivitas $\geq 1500$ MET menit. Adapun yang dimaksud MET (Metabolic Energy Turnover) aktivitas fisik berat adalah lamanya waktu (menit) melakukan aktivitas dalam satu minggu dikalikan bobot sebesar 8 kalori. MET merupakan perbandingan antara metabolisme saat bekerja dengan laju metabolisme saat istirahat yang di gambarkan dengan satuan $\mathrm{kg} / \mathrm{kkal} / \mathrm{jam}$. Dengan demikian aktivitas fisik merupakan kegiatan yang perlu untuk dilakukan oleh siapapun terutama wanita usia subur yang merupakan kelompok rentan terhadap kejadian overweight.

\section{Hubungan Riwayat Keluarga dengan Overweight}

Berdasarkan hasil penelitian diperoleh hasil bahwa riwayat keluarga tidak memiliki hubungan yang singnifikan dengan kejadian overweight pada wanita. Berdasarkan hasil analisis distribusi data hamper sebagian besar responden (wanita usia subur) yaitu sebanyak 222 orang $(80,4 \%)$ tidak memiliki riwayat 
orang tua (bapak/ibu) nya mengalami overweight atau obesitas, sehingga hasil analisis komparatif dinyatakan bahwa riwayat keluarga tidak signifikan terhadap kejadian overweight.

Hasil ini menguatkan asumsi bahwa apabila responden dengan orang tua yang memiliki status gizinya overweight secara langsung resesif pada keturunannya mengingat proporsi sel lemak ibu pada saat dalam kehamilannya menurunkan ke anaknya. Overweight dapat diturunkan dari generasi sebelumnya pada generasi berikutnya didalam sebuah keluaga. Hal ini lah yang menyebabkan kita sering kali menjumpai orang tua yang gemuk cenderung memiliki anak-anak yang gemuk pula. Dalam menentukan jumlah unsur sel lemak dalam tubuh. Hal ini mungkin karena pada saat ibu yang obesitas sedang hamil maka unsur sel lemak yang berjumlah besar dan melebihi ukuran normal, secara otomatis akan diturunkan kepada sang bayi selama dalam kandungan. Maka tidak heranlah bila bayi yang lahir pun memiliki unsur lemak tubuh yang relatif sama besar (Hasdianah dkk, 2014). Bila kedua orang tua mengalami obesitas maka $80 \%$ anaknya akan mengalami obesitas, bila salah satu orang tua obesitas maka kejadian obesitas menjadi $40 \%$ dan bila kedua orang tua tidak mengalami obesitas prevalensi menjadi $14 \%$ (Permatasari dkk, 2013).

Penelitian ini sejalan dengan penelitian yang dilakukan oleh Puspitasari (2018), hasil penelitian menunjukkan bahwa terdapat hubungan antara riwayat keluarga dengan kejadian obesitas pada usia dewasa dan responden yang memiliki riwayat keluarga berisiko 1,5 kali lebih besar terkena obesitas dibandingkan dengan responden yang tidak memiliki riwayat keluarga. Hal ini juga sejalan dengan penelitian yang dilakukan oleh Ali \& Nuryani (2018) menunjukkan hasil statistik diperoleh nilai $\mathrm{OR}=2,016$ yang artinya riwayat orang tua merupakan faktor risiko terhadap kejadian overweight pada remaja. Riwayat overweight pada orang tua meningkatkan risiko obesitas 2,016 kali pada remaja.

Hasil penelitian ini didukung oleh penelitian yang dilakukan oleh Savitri (2017) menunjukkan adanya hubungan yang signifikan antara riwayat overweight pada keluarga dengan obesitas, pada penelitian ini yang dianggap sebagai pembawa riwayat overweight adalah ibu dan ayah. Jika salah satu dari orang tua atau keduanya memiliki riwayat obesitas, maka terdapat risiko bagi seorang anak mengalami obesitas. Riwayat keluarga memiliki risiko 0,3 kali lebih besar dari responden yang tidak memiliki riwayat obesitas pada keluarga.

Namun berbeda dengan penelitian Patsopoulou et al (2016) menunjukkan bahwa tidak terdapat hubungan yang signifikan antara riwayat obesitas dan overweight ayah dengan kejadian obesitas pada remaja $p$ value $=$ 0,080 dengan nilai $\mathrm{RR}=1,49$, dibandingkan dengan status gizi normal kedua orang tua. Yang berarti bahwa responden yang memiliki riwayat orang tua yang mengalami overweight lebih berisiko 1,49 kali menderita overweight.

\section{Hubungan Penggunaan Alat Kontrasepsi dengan Overweight}

Berdasarkan hasil penelitian diperoleh bahwa penggunaan alat kontrasepsi tidak ada hubungan yang signifikan dengan kejadian overweight pada wanita. Dari hasil penelitian diketahui bahwa penggunaan alat kontrasepsi hormonal diketahui hanya $56 \quad(33,3 \%)$ berisiko menjadi overweight, sedangkan sebaliknya 112 $(66,7 \%)$ mengalami berat badan normal.

Hasil penelitian ini sejalan dengan penelitian yang dilakukan oleh Hasan dkk (2013) menunjukkan tidak terdapat hubungan antara penggunaan kontrasepsi dengan overweight dengan nilai $p$ value $=0,585$. Hal tersebut dipengaruhi oleh wanita usia subur memiliki aktivitas fisik yang tinggi dan tingkat pendidikan yang cukup tinggi pula.

Hal ini juga sejalan dengan penelitian yang dilakukan oleh Mulyaningsih (2016) yang menunjukkan tidak ada hubungan antara penggunaan alat kontrasepsi dengan kejadian overweight pada karyawati. Berdasarkan hasil penelitian ini dapat disimpulkan bahwa tidak terdapat hubungan antara penggunaan alat kontrasepsi dengan kejadian overweight. Hal ini dinyatakan bahwa pekerjaan dan aktivitas fisik sedang dan berat membutuhkan energi dan kalori yang cukup besar sehingga tidak terjadi penumpukan energi dan lemak di dalam tubuh.

Hal tersebut bertentangan dengan teori yang menyatakan bahwa peningkatan berat badan pada pemakaian kontrasepsi disebabkan hormon dalam kontrasepsi yaitu esterogen dan progesteron. Esterogen menyebabkan pengeluaran natriun dan air berkurang sehingga terjadi penimbunan cairan (Wiknjosastro, 2005) sedangkan progesteron akan mempermudah perubahan karbohidrat dan gula menjadi lemak, merangsang nafsu makan serta menurunkan aktivitas fisik sehingga terjadi peningkatan berat badan.

Hal tersebut sejalan dengan penelitian yang dilakukan oleh Salim (2014) menunjukkan ada hubungan antara alat kontrasepsi dengan kejadian overweight dengan nilai $p$ value $=0,030$ dengan nilai $\mathrm{OR}=4,063$ yang berarti bahwa responden yang menggunakan alat kontrasepsi memiliki risiko 4,063 kali mengalami overweight. Pendapat yang sama dari penelitian yang dilakukan oleh Khoiriah (2016) menunjukkan terdapat ada hubungan yang signifikan anatara penggunaan alat kontrasepsi dengan kejadian overweight dengan nilai $p$ value $=0.001$ dengan nilai $\mathrm{OR}=5,4$ yang berarti bahwa responden yang menggunakan alat kontrasepsi hormonal berisiko 5,4 kali menderita overweight dibandingkan dengan responden yang tidak menggunakan alat kontrasepsi hormonal. 
Menurut teori pemakaian alat kontrasepsi dapat memengaruhi peningkatan berat badan yang disebabkan oleh hormone didalam kontrasepsi yaitu estrogen dan progesterone. Namun perbedaan hasil penelitian ini diperkirakan berdasarkan distribusi data yang ditemukan karena disebabkan adanya fakta bahwa pekerjaan responden sebagian besar sebagai ibu rumah tangga yang memiliki aktivitas fisik yang digolongkan berat $(81,9 \%)$ dan pendidikan wanita usia subur dilokasi penelitian cukup tinggi sebesar $66,6 \%$ sehingga mengerti tentang overweight dan faktor risiko seperti pola makan, aktivitas dan penggunaan alat kontrasepsi.

\section{SIMPULAN}

Berdasarkan hasil penelitian dapat disimpulkan bahwa prevalensi overweight pada wanita usia subur sebesar 35,5\%, pola makan buruk sebesar 50,4\%, aktivitas fisik berat sebesar $81,9 \%$, tidak ada riwayat overweight/obesitas sebesar $80,4 \%$ dan pemakaian alat kontrasepsi hormonal sebesar $60,9 \%$. Dari beberapa determinan kejadian overweight diketahui bahwa pola makan merupakan faktor risiko overweight sedangkan aktivitas fisik, riwayat keluarga dan penggunaan alat kontrasepsi bukan merupakan faktor risiko kejadian overweight pada wanita usia subur di wilayah kerja Puskesmas Simpang Kawat Kota Jambi Tahun 2019.

\section{DAFTAR PUSTAKA}

Almatsier, S. (2009). Prinsip Dasar Ilmu Gizi. Jakarta: PT Gramedia Pustaka Utama.

Ali, R., \& Nuryani. (2018). Sosial Ekonomi, Konsumsi Fast Food dan Riwayat Obesitas Sebagai Faktor Risiko Obesitas Remaja. Media Gizi Indonesia, 13(2), 123-132.

Dinas Kesehatan Kota Jambi. (2016). Data Penyakit Obesitas di wilayah Puskesmas Kota Jambi Tahun 2016. Jambi: Dinas Kesehatan Kota.

Dinas Kesehatan Kota Jambi. (2017). Data Penyakit Obesitas di wilayah Puskesmas Kota Jambi Tahun 2017. Jambi: Dinas Kesehatan Kota.

Dinas Kesehatan Kota Jambi. (2018). Data Penyakit Obesitas di wilayah Puskesmas Kota Jambi Tahun 2018. Jambi: Dinas Kesehatan Kota.

Diana, R., Yuliana, I., Yasmin, G., \& Hardinsyah. (2013). Faktor risiko kegemukan pada wanita dewasa Indonesia. Jurnal Gizi dan Pangan, 8(1), $1-8$.

Evan, W.J., \& Candrawati, E. (2017). Hubungan antara pola makan dengan kejadian obesitas pada mahasiswa di Universitas Tribhuwana Tunggadewi Malang. Nursing News, 2(3), 708717.

Hardiansyah., \& Supariasa, I.D.N. (2016). Ilmu Gizi Teori dan Aplikasi. Jakarta: EGC.

Hasdianah., Siyoto, S., \& Yuly, P. (2014). Gizi Pemanfaatan Gizi, Diet, dan Obesitas. Yogyakarta.
Hasan, M., Malyulu, N., \& Kawengian, S. (2013). Hubungan penggunaan kontrasepsi hormonal dengan obesitas pada wanita usia subur (WUS) di Puskesmas Wawanosa Kecamatan Singkil Manado. Jurnale-Biomedik, 1(2), 946-950.

Kemenkes RI. (2018). Riset Kesehatan Dasar. Jakarta: Balitbang Kemenkes RI.

Khoriah, A. (2016). Hubungan penambahan berat badan pada akseptor kontrasepsi hormonal di BPM Zuniawati Palembang. Jurnal Kesehatan, 7(2), 271-276.

Merawati, D., \& Kinanti, R.G. (2005). Perilaku makan pada siswa obesitas. J Iptek Olahraga, 7(3), 182192.

Miko, A., \& Pratiwi, M. (2017). Hubungan pola makan dan aktivitas fisik dengan kejadian obesitas mahasiswa Politeknik Kesehatan Kemenkes Aceh. Action Jurnal, 2(1), 1-5.

Mulyaningsih, R.E.M., \& Sudrajat, F.B. (2016). Hubungan penggunaan KB hormonal dengan kejadian obesitas pada wanita usia subur Di wilayah kerja Puskesmas Kejaksan Kota Cirebon. Tunas Medika Jurnal Kedokteran dan Kesehatan, 3(2), 1-6.

Nova, M., \& Yanti, R. (2017). Faktor-faktor yang berhubungan dengan obesitas pada orang dewasa di Kota Padang Panjang. Nutri-Sains, 1(1).

Patsopoulou, A., Tsimtsiou, Z., Katsioulis, A., Rachiotis, G., Malissiova, E., \& Hadjichristodoulou, C. (2016). Prevalence and risk factors of overweight and obesity among adolescents and their parents in Central Greece (FETA project). International Journal of Environmental Research and Public Health, 13(83), 1-10.

Permatasari, I., Mayulu, N.R.I., \& Hamel, R. (2013). Analisa riwayat orang tua sebagai faktor risiko obesitas pada anak SD di Kota Manado. Ejournal Keperawatan, 1, 1-7.

Puspitasari, N. (2018). Faktor kejadian obesitas sentral pada usia dewasa. Jurnal HIGEIA, 2(2), 249-259.

Putra, N.W. (2017). Hubungan pola makan, aktivitas fisik dan aktivitas sedentari dengan overweight di SMA Negeri 5 Surabaya. Jurnal Berkala Epidemiologi, 5(3), 298-310.

Rizka, R.A., Rahayu, I., \& Yustini. (2014). Hubungan pola makan dengan kejadian obesitas pada remaja di SMA Katolik Cendrawasih. EJournal Universitas

Hasanudin.http://repository.unhas.ac.id/handle/12 3456789/10878.

Salim, A.N. (2014). Faktor-faktor yang berhubungan dengan kejadian obesitas pada karyawati sekretariat daerah Kabupaten Wonosobo. Fakultas Ilmu Keperawatan dan Kesehatan Universitas Muhammadiyah Semarang. Semarang.

Savitri, A. (2017). Faktor-faktor yang berhubungan dengan kejadian obesitas sentral pada wanita usia- 
15-44 tahun di Posbindu Wilayah Kerja Puskesmas Kecamatan Pasar Minggu Jakarta Selatan Tahun 2017. Universitas Islam Negeri Syarif Hidayatullah. Jakarta.

Sirajuddin., Surmita., \& Astuti, T. (2018). Survey Konsumsi Pangan. Jakarta: Kemenkes, RI.

Sulistyoningsih, H. (2011). Gizi untuk Kesehatan Ibu dan Anak. Yogyakarta: Graha Ilmu.

Wiknjosastro, H. (2005). Ilmu Kandungan. 3rd ed. Jakarta: Yayasan Bina Pustaka Sarwono Prawirohardjo.

World Health Organization (WHO). (2018). Obesity and Overweight 2018 February (online). Diunduh dari URL: $\quad$ http://www.who.int/en/news-room/factsheets/detail/obesity-and-overweight. (Diakses $15 / 08 / 2018)$.

World Health Organization (WHO). (2019a). Physycal Activity (online). Diunduh dari: URL: http://www.who.int/ (Diakses 22 Januari 2019).

World Health Organization (WHO). (2019b). GPAQ Instrument and Analysis Guide $v 2$ (online). Diunduh dari URL: http://www.who.int/chp/steps/ (Diakses 22 Januari 2019).

Yulianawati, R. (2016). Hubungan pola makan dengan tingkat obesitas pada mahasiswa ilmu keperawatan di Universitas 'Aisiyiyah Yogyakarta. [Naskah Publikasi]. Universitas 'Aisiyiyah Yogyakarta. 